\title{
Vai Language
}

National Cancer Institute

\section{Source}

National Cancer Institute. Vai Language. NCI Thesaurus. Code C154190.

A Niger-Congo Mande language spoken by the Vai people in Liberia and Sierra Leone. 